\title{
The Adoption of Sustainable Facilities Management Practices in Organisations: A study of Malaysian universities
}

\author{
Mohamad Sufian Hasim, Ahmad Sharim Abdullah, Abdul Rauf Abdul Rasam, Hafiszah Ismail \\ Faculty of Architecture, Planning and Surveying, \\ Universiti Teknologi Mara, Shah Alam, 40450, Malaysia
}

moham315@uitm.edu.my; sharim@uitm.edu.my; rauf@uitm.edu.my; hafiszah@uitm.edu.my

Tel: +60196765200; +603-55444386

\begin{abstract}
Globally, there is a growing trend among organisations towards promoting sustainability as an essential business strategy due to a high level of awareness about the impacts of their operations on the triple bottom line. This paper aims to examine the implementation of sustainability practices in an organisation focusing on universities. The objective was to determine sustainability adopted in facilities management (FM) practice concerning three different sustainability dimensions. Sixteen (16) interviews were conducted with the senior managerial level in selected universities. Among all dimensions, environmental sustainability was widely focused on having higher priorities for energy efficiency, waste reduction, and water conservation. These results provided some explanation and understanding of the overall picture of the study about organisational commitment towards sustainability in facilities management.
\end{abstract}

Keywords: Sustainable Facilities Management; Malaysian Universities; Sustainable Organisation; Facilities Management

eISSN: 2398-4287 @ 2020. The Authors. Published for AMER ABRA cE-Bs by e-International Publishing House, Ltd., UK. This is an open access article under the CC BYNC-ND license (http://creativecommons.org/licenses/by-nc-nd/4.01. Peer-review under responsibility of AMER (Association of Malaysian Environment-Behaviour Researchers), ABRA (Association of Behavioural Researchers on Asians) and cE-Bs (Centre for Environment-Behaviour Studies), Faculty of Architecture, Planning \& Surveying, Universiti Teknologi MARA, Malaysia.

DOI: https://doi.org/10.21834/e-bpj.v5i13.1898

\subsection{Introduction}

Buildings have a significant effect on the natural environment such as land degradation, deforestation, waste generation and greenhouse gas (GHG) emissions which are associated with climate change (Intergovernmental Panel on Climate Change, 2007; Metz, Davidson, Bosch, Dave, \& Meyer, 2007). With current development trends, it is predicted that in the long term, these consequences will be more severe (Environmental Protection Agency, 2013; United Nations Environment Programme, 2009). Therefore, all parties involved in constructing and managing buildings urged to develop and operate buildings in a sustainable way in minimising the adverse effects on the natural environment.

This research aims to examine the implementation of sustainability in facilities management (FM) practices for a public organisation. The research setting is universities as these institutions are in a unique position to influence the attitudes of the community, government and the private sector towards sustainability. Universities are regarded as one of the crucial research settings and can play a fundamental role in achieving sustainability goals (Wright \& Wilton, 2012). According to the Association of University Leaders for a Sustainable Future (ULSF 1999) 'universities can be involved in sustainable development such as in management, planning, development, education, research, operations, community service, purchasing, transportation, design, new construction, renovation and retrofit'. Thus, the findings from these organisations can be used as a benchmark in gauging the commitments of other organisation in adopting sustainability.

eISSN: 2398-4287 (C) 2020. The Authors. Published for AMER ABRA cE-Bs by e-International Publishing House, Ltd., UK. This is an open access article under the CC BYNC-ND license (http://creativecommons.org/licenses/by-nc-nd/4.0/). Peer-review under responsibility of AMER (Association of Malaysian Environment-Behaviour Researchers), ABRA (Association of Behavioural Researchers on Asians) and cE-Bs (Centre for Environment-Behaviour Studies), Faculty of Architecture, Planning \& Surveying, Universiti Teknologi MARA, Malaysia.

DOI: https://doi.org/10.21834/e-bpj.v5i13.1898 
Organisational efforts to put sustainability into practice have been reported in numerous publications. However, most of this literature reports on the situation in developed countries (i.e. North America and Europe), and evidence from developing countries is much less common. In addressing this knowledge gap, there needs to be research on the extent of sustainability adoption into FM practices and an examination of the commitment of the public organisation in developing countries such as Malaysia toward sustainability. This study is significant, especially for developing countries as they need new knowledge to accelerate their effort to improve sustainable practice in FM and expand their organisational sustainability outcomes.

\subsection{Literature Review}

Sustainability is not a new concept (Warren-Myers, 2013) and has widely influenced global business practice (Koukiasa, 2011). Generally, the agenda is commonly connected with three dimensions aiming to optimize environmental protection, economic viability and social progress (Hitchcock \& Willard, 2006; Petrini \& Pozzebon, 2010). Figure 1 illustrates these three dimensions.

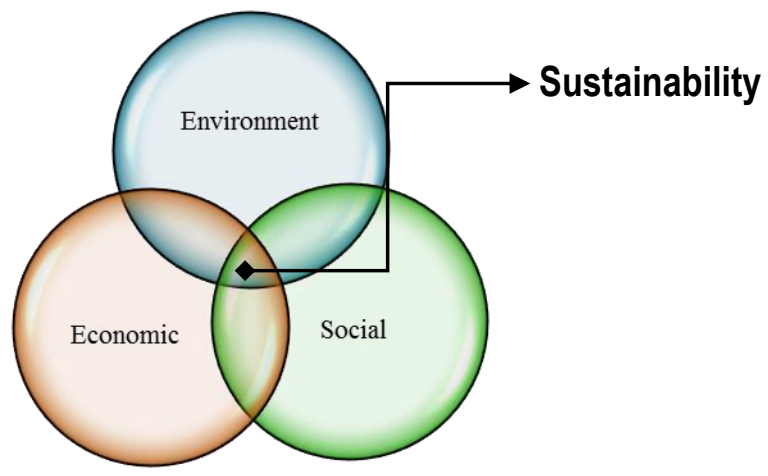

Fig. 1: Dimensions of sustainability

(Source: Adopted and adapted from Beheiry, Chong \& Haas 2006; Khalfan 2002; Shelbourn et al. 2006)

Ideally, organisations can only be considered to be moving towards sustainability if all three dimensions are adopted into practices (Boyle, 2003). The connection of these three dimensions can be seen in such a way that, for example, if an environmental dimension were adversely affected, it would minimize the critical resources that were needed to advance the economy. If the economy were damaged, unemployment would be high, thus creating many social problems and leading to an unstable community. A volatile community would be too focused on the issues that they faced and would not be concerned about environmental degradation (Hitchcock \& Willard, 2006) and, consequently, would not be bothered about sustainability. This is consistent with Robinson (2004), who argued that all three dimensions need to be effectively integrated to achieve long-term sustainability goals.

\subsection{Dimensions of sustainability}

In gaining a better understanding, the following sub-sections clearly describe each of the sustainability dimensions:

\section{a) Environmental sustainability}

Environmental sustainability is concerned with ecosystem health, biodiversity, resource consumption including energy and water usage, climate change and land use (Boyle, 2003; Curran, 2009). According to Goodland (1995), this approach is related to maintaining sustainable levels of both resources and consumption. In this case, resource capacities of the global ecosystem provide raw materials, water, air and energy, whereas consumption capacities assimilate outputs or wastes. Over the last 20 years, there has been increasing awareness globally about environmental sustainability due to the impact of development (Woodruff \& Mankoff, 2009). Urgent solutions are required to minimize the detrimental effects of environmental challenges such as climate change, ozone depletion, pollution, soil degradation and deforestation (Banerjee, 2002; Hansen, 2006). From the built environment perspective, environmental sustainability addresses the impact of construction and maintenance activities on the environment by minimizing the use of resources, reducing the production of waste and pollution, protecting biodiversity and the natural environment, and using energy efficiently. Indeed, the transition to environmental sustainability is crucial because the deterioration rate of global life support systems that create the environment imposes a time limit for achieving results.

\section{b) Economic sustainability}

The concept of economic sustainability is widely accepted as having the objectives of enabling businesses to be efficient and competitive, supporting local economic diversity and providing employment opportunities. However, the concept is still not wholly defined even 50 years after the origins of the sustainability agenda, and this creates a difficulty especially when an organisation attempts to integrate sustainability into their management operation (Shriberg, 2002). Various definitions have been highlighted, for example, the need to maintain a permanent income for humankind which is generated from non-declining capital stocks (Spangenberg, 2005). Shriberg (2002) proposed that the scale of the economy be minimized to be consistent with the ecology of the earth. Moreover, Khalfan (2002), suggested the economic sustainability is concerned with activities such as the investment in people and equipment for a 
competitive economy, job opportunities, improving the local economy, creation of new markets, prospects for sales growth, cost reduction and raw material inputs. Furthermore, it can be considered as the catalyst behind sustainability practices in general which means that any initiatives undertaken to sustain other dimensions such as environmental and social must rely on this economic dimension (Boyle, 2003). This means that, in promoting sustainability initiatives or activities, profitability or an acceptable level of profit is needed to ensure the ongoing operation of the organisation. From the organisational perspective, economic sustainability is used to evaluate possible strategies in which to be engaged by considering their returns and the availability of resources for long-term benefits (Tatum, 2013) and, in most situations, economic sustainability is measured in financial terms.

\section{c) Social sustainability}

The social sustainability dimension is not highlighted as much in research compared to environmental and economic sustainability (Dempsey, Bramley, Power, \& Brown, 2011; Gladwin, Krause, \& Kennelly, 1995; Parkin, Sommer, \& Uren, 2003). According to Barbier (1987), social sustainability is 'the ability to maintain desired social values, traditions, institutions, cultures, or other social characteristics' (p. 610). Moreover, Littig and Griessler (2005) defined social sustainability as being 'a quality of societies. It signifies the nature-society relationships, mediated by work, as well as relationships within the society' (p. 72). This dimension is concerned with social capital, human health, poverty, civil justice, a fair distribution of resources, consumption patterns, human development and the integration of environment and development in decision making (Boyle, 2003; Gladwin et al., 1995). However, while these concepts are widely accepted, the meaning has been neither well-defined nor agreed upon (Dempsey et al., 2011; Shriberg, 2002).

\subsection{An overview of sustainable facilities management}

The FM is concerned with managing assets and facilities in the operations and maintenance phase which involves the management of energy, water and waste in alignment with related policies and guidelines (Lavy, 2008; Lee \& Kang, 2013). Although FM covers various functions such as project management, maintenance management and space management (Reineck, Poltermann, May, \& Pelzeter, 2012), it always refers to managing buildings efficiently, particularly during the operations phase. This action to assist the organisation's core business in reducing the impact of buildings on the built environment (Moller \& McCartney, 2007). Moreover, FM is understood to be an activity that has its emphasis on the same fundamental elements which are place, process and people to achieve organisational goals with a shared idea of the 'integration' of those elements (Kumagai, 2001). Figure 2 shows the three elements of FM.

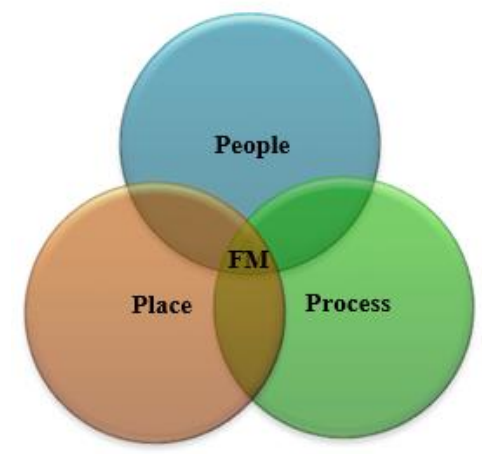

Fig. 2: The FM triangle

(Source: Adopted and adapted from Finch and Zhang (2013)

The critical task of FM managers is how to effectively manage these three elements to support the core function of the organisation (Ogbeifun, 2011). Thus, the integration of these three elements is vital for organisational performance. Indeed, FM is one of the crucial aspects of the built environment, and many organisations have now started to realize the strategic role of FM in providing benefits from the investment in assets and facilities (Pathirage, Haigh, Amaratunga, \& Baldry, 2008). Thus, sustainable practice in FM is the process which facilitates the organisation's ability to become more sustainable, and concurrently enhances the organisation's ability to achieve sustainability by optimizing environmental, financial and social dimensions (Koukiasa (2011).

Sustainable practices in FM are not only crucial for the management of new assets but, at the same time, they are essential for managing existing assets. Various commercial organisations have shown their concerns with regard to the existing building stock by focusing on resource efficiency, primarily in the areas of energy, water and waste (Warren-Myers, 2013). As the amount of existing buildings is substantial (Elle, Hoffman, Nielsen, \& Jensen, 2005), sustainability practices for such buildings are thus vital as they can provide a positive impact in the transformation towards achieving a sustainable society (Nielsen, Jensen, \& Jensen, 2012). According to Rick Fedrizzi, CEO of USGBC, as cited in Mayton (2007), the market of existing buildings is 16 times larger than that of new construction, and thus it has a crucial impact on climate change. Moreover, sustainability practices for existing building stock are essential because this involves the operation and maintenance (O\&M) stage which is the longest phase in the asset life cycle dealing with both embodied (used for manufacture) and operational energy (used for operation). Pullen (1999) argued that approximately $25 \%$ of the life-cycle energy consists of embodied energy. This means that it is critically important to manage assets with sustainable practices in order to optimize energy use and minimize the use of resources 


\subsection{Organisational commitment to sustainability}

Sustainable practices are essential for organisations as they have a significant influence on organisational success. Globally, there is a growing trend among organisations towards promoting sustainability as a critical business strategy due to a high level of awareness about the impacts of their operations on society and the environment (Bertels, Papania, \& Papania, 2010; Petrini \& Pozzebon, 2010; Vanegas, 2003). For example, in the 2010 UN Global Compact-Accenture CEO Study, more than $90 \%$ of CEOs agreed that the sustainability agenda is vital for their future organisational achievements. For example, a study by PricewaterhouseCoopers in 2002 for the USA revealed that $75 \%$ of companies surveyed were adopting some sustainability practices, $73 \%$ planned to issue a sustainability report and $89 \%$ expected sustainability to be more critical after five years (Hitchcock \& Willard, 2006).

Sustainability at the organisational level refers to enhancing the firm's profitability, adopting and pursuing ethical business practices, creating sustainable jobs, building value for all stakeholders and, at the same time, meeting environmental and social needs (Porter, 2008; Székely \& Knirsch, 2005). Generally, organisations are adopting sustainability into practice when they are using environmentallysafe cleaning products; renewable energy for lighting and transportation; recycling or reuse of all waste; applying leadership to influence the industry. However, for the more successful organisation, sustainability principles must penetrate into all aspects of the organisation (Hitchcock \& Willard, 2006) and not be a piecemeal approach. Thus, organisations must embed the sustainability agenda within their organisational structure and governance, such as by establishing a vision and mission policy incorporating sustainability.

\subsection{Methodology}

This study engaged face-to-face semi-structured interviews to gather in-depth information from participants of their perceptions. Appropriate key participants were selected based on their position's rank in the specific department dealing with the asset life cycle such as the managerial positions in the planning and design department, engineering department, or maintenance department. It was recognized that senior positions are more knowledgeable and would deliver reliable information concerning activities being undertaken, in planning and future developments (Warren-Myers, 2013). A well-structured series of questions was required for this research, and this would provide the whole picture of all of the issues that needed severe thought in addressing the research questions and objectives (Yin, 1994). In achieving study objectives, four universities were chosen to represent different groupings of Malaysian universities, 'Research University' and 'Comprehensive University'. Table 1 shows the list of universities involved and the number of participants.

Table 1: List of universities

\begin{tabular}{|c|c|l|}
\hline University & $\begin{array}{c}\text { Nos. of } \\
\text { Participants }\end{array}$ & \multicolumn{1}{c|}{ Group } \\
\hline$(\mathrm{A})$ & 4 & Comprehensive University (CU) \\
\hline$(\mathrm{B})$ & 4 & Research University (RU) \\
\hline$(\mathrm{C})$ & 5 & Research University (RU) \\
\hline$(\mathrm{D})$ & 3 & Research University (RU) \\
\hline
\end{tabular}

Four participants from each university were generally invited to participate in this study, with a total of 16 interviews were conducted. Guest, Bunce and Johnson (2006) suggested that a range between six and 12 participants for interviews was adequate for developing meaningful themes and achieving research objectives. Thus, with those numbers, this study conformed to this suggestion. However, as a limitation of this interview, the researcher, as an objective observer, did not conduct any observation on body language, gestures or other associated signals during the interview session. In addition, no photos were taken during the processes, and the interviews were in a mixture of English and the Malay language. The specific themes of the questions related to the objective of the study were 'Key initiatives were undertaken and performance'. The interview results contributed to determine sustainability initiatives in university FM practice and identify the indicators which highlight these initiatives. Participants' opinions were summarised and evaluated to assess how these opinions varied based on their understanding, and the themes were presented in the form of tables to get a clear picture. Where appropriate, the results were presented by incorporating a ranking of the themes which was derived from the total number of statements (mentioned by the participants across all of the interviews) and not by the number of participants. The total number of statements may, therefore, be higher than the number of participants. This ranking could be assumed from the priorities that participants have given to the themes (Marlow, 2008). In addition, typical and relevant participants' quotations were included to portray expert opinions and to assist in making conclusions.

\subsection{Findings}

This section portrays significant results concerning the extent of sustainability adoption in FM practices based on dimensions of the triple bottom line consists of the environmental, economic and social dimension. The results indicated that, among the three sustainability dimensions, the environmental performance was the most widely focused in their FM practices. Details of the initiatives undertaken are described in the following sections.

\subsection{Environmental sustainability}

Overall, the study identified eight (8) relevant themes for the environmental initiatives undertaken which were established based on participants' descriptions. Table 2 provides the list of environmental initiatives ranked showing the number of statements and percentage distribution. 
Table 2: Environmental sustainability initiatives - Ranking of themes

\begin{tabular}{|l|l|c|c|}
\hline \multicolumn{1}{|c|}{ Theme } & \multicolumn{1}{|c|}{ Description of Initiatives } & $\begin{array}{c}\text { No. of } \\
\text { Statements }\end{array}$ & (\%) \\
\hline 1. Energy & Energy efficiency - (zoning, installing efficient technology (i.e. LED lights, sensors) & 11 & 30 \\
\hline 2. Waste & Reduction/recycling & 10 & 27 \\
\hline 3. Water & Conservation/reduction/recycling/reuse (i.e. for irrigation, rainwater harvesting) & 8 & 22 \\
\hline 4. Green building & Implementing the Green Building Index (GBI) rating system (i.e. Platinum) & 2 & 5 \\
\hline 5. Biodiversity & Preservation - green landscaping, replanting trees & 2 & 5 \\
\hline 6. Champion & Appointing/forming a special position (Energy Manager, Committee) & 2 & 5 \\
\hline 7. Environmental policy & $\begin{array}{l}\text { In new projects or buildings - embedding sustainable policy/plan/guidelines (i.e. } \\
\text { environmental management plan) }\end{array}$ & 1 & 3 \\
\hline 8. Building Management System & Developing a system for control and monitoring & 1 & 3 \\
\hline \multicolumn{1}{|c|}{ TOTAL } & 37 & 100 \\
\hline
\end{tabular}

Universities in Malaysia were identified as having higher priorities for both energy efficiency (30\%) and waste reduction (27\%). Moreover, water conservation (22\%) initiatives were among crucial initiatives that had priority, for example, the introduction of rainwater harvesting for new building projects. Participants mentioned that:

'... one significant initiative that we have undertaken was a rainwater harvesting system for new buildings. At the moment, we have four as a pilot project ... and then we recycle the water ... we collect and reuse it directly or filtered ...' (participant \#10, MY).

"... yes, we have a target to be a zero-waste campus by 2015 , and now maybe we recycle only $20 \%$ with $80 \%$ still going to landfill ... here we also have a water harvesting system for rainwater. We put in a tank to harvest the water and then put it back for toilet use ... that system is only for the new buildings ..." (participant\#11, MY).

\subsection{Economic sustainability}

In terms of economic sustainability, the study revealed much more limited information from university organisation. The study revealed the economic initiatives only were via cost reduction approaches. This can be seen in the standardization of design requirements using the same materials, systems and equipment, and the use of facing bricks (bricks intended to be visible) to reduce the painting costs. Interestingly, universities had an initiative which involved engaging local contractors and utilising local products for their projects. This was mentioned by one participant who stated that:

'... so we are looking for local contractors ... in the tender invitation notice, we put that our advertisement is open to local registered contractors [aboriginal] only ...' (participant \#5, MY).

\subsection{Social sustainability}

Overall, five (5) social initiative themes emerged which were relevant to social sustainability. Table 3 provides a list of social initiatives undertaken in Malaysian universities ranked by the number of statements and percentage distribution.

Table 3: Social sustainability initiatives - Ranking of themes

\begin{tabular}{|l|l|c|c|}
\hline \multicolumn{1}{|c|}{ Theme } & \multicolumn{1}{|c|}{ Description of Initiatives } & $\begin{array}{c}\text { No. of } \\
\text { Statements }\end{array}$ & (\%) \\
\hline $\begin{array}{l}\text { 1. Participation and } \\
\text { involvement }\end{array}$ & $\begin{array}{l}\text { Consultation/participation from various groups (i.e. campus } \\
\text { community, local community) }\end{array}$ & 9 & 50 \\
\hline 2. Increasing human capital & $\begin{array}{l}\text { Knowledge enhancement - education, training, further studies, site } \\
\text { experiences, establishing websites, publicity campaigns (i.e. posters } \\
\text { on various themes) }\end{array}$ & 4 & 22 \\
\hline 3. Health and safety & $\begin{array}{l}\text { Occupants' health and safety - of people, productivity benefit, safety } \\
\text { monitoring }\end{array}$ & 3 & 17 \\
\hline 4. Public access & $\begin{array}{l}\text { Access to facilities - changing operational nature of building for more } \\
\text { flexibility, disabled access path provided }\end{array}$ & 1 & 5.5 \\
\hline 5. Occupiers' satisfaction & Surveys on customer satisfaction & 1 & 5.5 \\
\hline \multicolumn{1}{|c|}{ TOTAL } & 18 & 100 \\
\hline
\end{tabular}

Specifically, the key initiatives undertaken by FM departments in Malaysian universities for social sustainability were participation and involvement of the community $(50 \%)$, increasing human capital $(22 \%)$ and occupants' health and safety (17\%). Participants stated that:

\footnotetext{
'... Before we implement any project, we organise a briefing ... We invite relevant faculties and students. We ask them their view and requirements ... For example, I have implemented one project called 'eco-terrace' which was a commercial building for students who are interested in small business ... So, we have collaboration with the Faculty of Architecture to give their input to achieve the aim of the project ... We discussed with them and developed an idea ...' (participant \#10, MY).

'... for social initiatives, we have a committee on human well-being. Its function is to study the level of satisfaction among the campus community who live on the university campus. Currently, they have started their research on this matter ...' (participant \#12, MY).

'... in terms of safety, we already have some guidelines which are from OSHA (Occupational Safety and Health Act) and the Occupational Health Unit ... to monitor safety and health-related issues ... we also have ... a campaign to enhance awareness and education about energy and water savings ...' (participant \#2, MY).
}

\subsection{Discussion}

Considering results found, the environmental sustainability dimension was emphasised in practice by universities' FM in Malaysia. Conversely, in order to fulfil social dimension needs, university FM is seen to be more concerned with reaching other institutional 
objectives such as providing extra spaces for new students, with little consideration for other activities and this leads them to follow tradition in their FM strategy consistently. This is not unexpected since most studies so far lead to similar conclusions. Although findings generally show that economics is the central theme for FM and particularly in reducing costs to maintain sustainability, the majority of studies consistently found that environmental sustainability plays a significant role in FM implementation (Beheiry, Chong, \& Haas, 2006; Nielsen \& Galamba, 2010; Wright \& Wilton, 2012). As for environmental dimension initiatives, the universities embarked on pollution control, water and biodiversity initiatives. Studies in these areas, particularly in Western countries, have explicitly discovered that energy, water, waste and pollution are among the significant issues in sustainability practices (Brown \& Pitt, 2001; Hodges, 2005; Warren-Myers, 2013). Moreover, this scenario seems to be confirmed by Elmualim, Shockley, Valle, Ludlow, and Shah (2010), namely, that energy management and waste recycling are the key issues identified in sustainability policies. This is also consistent with the growing body of research in FM which suggests waste management (Pitt, 2005; Zhang, Williams, Kemp, \& Smith, 2011) and energy management (Dahle \& Neumayer, 2001; Wood, 2006) are crucial sustainability issues.

Although limited information was revealed from interviews concerning economic sustainability, it seems that certain aspects were mentioned. There were efforts to reduce asset cost as part of universities' FM initiatives and to engage local contractors and use local products in the projects. In this context, findings for this study are consistent with the study by McCrudden and Gross (2006) who claimed that Malaysia had some policies for procurement practice that provides priority to improve the economic development of local (indigenous) Malays who are mainly involved with small business. For example, all works' contracts up to RM100,000 were kept for Malay contractors (McCrudden, 2004). Moreover, this research found that universities have adopted the standardization of design requirements using the same materials, systems and equipment. However, this research assumed that the limited information on this aspect from the interviews might be due to the unfamiliarity of the FM practitioner with the concept of economic sustainability compared to environmental and social sustainability. From a social perspective, the interviews revealed that increasing human capital and 'participation and involvement of the community' in their decision-making process was mostly taken into consideration. For example, some participants agreed that relevant stakeholders (i.e. campus and local communities) were to be invited to contribute opinions and suggestions during the planning of a new asset or facility.

In term of commitment and performances, it may be contributed to by several factors that affected effort towards sustainable practice within organisations. For example, although there were some initiatives to promote sustainability practices in FM, they were still far from being implemented. Universities in Malaysia were only at the early stages in their commitment toward sustainable FM practices. For example, interviews revealed that, currently, a university had started a pilot project on environmental initiatives such as rainwater harvesting and reuse of water for new buildings.

\subsection{Conclusion and Recommendations}

This research can be considered as part of a larger organisational effort in managing sustainability focused on universities. It represents a major advance by establishing empirical evidence on universities' performance on sustainable FM practice. This study has identified the level of sustainable practice in university FM, where universities in Malaysia were shown to be advanced on environmental sustainability. They gave priority to energy efficiency, water conservation and waste reduction programs. A commitment was shown by these organisation with various initiatives undertaken towards sustainable FM practices. Indeed, this new knowledge can be used by other organisations to advance their practice and ultimately reduce the impact of buildings on the natural environment.

As a recommendation, these initiatives potentially could be adopted and applied across a broader range of organisations such as government departments (hospitals, schools), the private sector and other building stock (asset owners) which will contribute to sustainability in the built environments. Universities can provide an example to encourage other building owners to make similar advances to accelerate the sustainable FM practices that would lead to achieving the sustainability goal.

\section{Acknowledgements}

The authors gratefully acknowledge the support grant in producing this paper under the Geran Penyelidikan LESTARI (Project Code: 600-IRMI/MyRA 5/3/LESTARI (056/2017) funded by Universiti Teknologi MARA, Malaysia. The authors would like to extend the appreciation to Associate Professor Dr Stephen Pullen and Dr Alpana Sivam from University of South Australia (UniSA), Adelaide, Australia, for their advice and guidance for this research.

\section{References}

Beheiry, S. M. A., Chong, W. K., \& Haas, C. T. (2006). Examining the business impact of owner commitment to sustainability. Journal of construction engineering and management, 132, 384.

Bertels, S., Papania, L., \& Papania, D. (2010). Embedding sustainability in organizational culture. A systematic review of the body of knowledge. London, Canada: Network for Business Sustainability.

Dempsey, N., Bramley, G., Power, S., \& Brown, C. (2011). The social dimension of sustainable development: Defining urban social sustainability. Sustainable Development, 19(5), 289-300. DOI: 10.1002/sd.417 
Elmualim, A., Shockley, D., Valle, R., Ludlow, G., \& Shah, S. (2010). Barriers and commitment of facilities management profession to the sustainability agenda. Building and Environment, 45(1), 58-64.

Finch, E., \& Zhang, X. (2013). Facilities management Design and Management of Sustainable Built Environments (pp. 305-326): Springer.

Guest, G., Bunce, A., \& Johnson, L. (2006). How Many Interviews are Enough? An Experiment with Data Saturation and Variability. Field methods, 18(1).

Hitchcock, D. E., \& Willard, M. L. (2006). The business guide to sustainability: practical strategies and tools for organizations. London, UK: Earthscan Ltd.

Intergovernmental Panel on Climate Change. (2007). Climate Change 2007: Mitigation. Contribution of Working Group III to the Fourth Assessment Report of the Intergovernmental Panel on Climate Change. The United Kingdom and New York, NY, USA: Cambridge University Press, Cambridge.

Koukiasa, M. (2011). Sustainable facilities management within event venues. Worldwide Hospitality and Tourism Themes, 3(3), 217-228.

Lavy, S. (2008). Facility management practices in higher education buildings: A case study. Journal of Facilities Management, 6(4), 303-315.

Lee, S. Y., \& Kang, M. (2013). Innovation characteristics and intention to adopt sustainable facilities management practices. Ergonomics (ahead-of-print), 1-12.

Metz, B., Davidson, O., Bosch, P., Dave, R., \& Meyer, L. (2007). Climate Change 2007 Mitigation: Contribution of Working Group III to the Fourth Assessment Report of the Intergovernmental Panel on Climate Change. Canada: Cambridge University Press New York, USA Retrieved from http://www.ipcc.ch/pdf/assessmentreport/ar4/wg3/ar4-wg3-frontmatter.pdf.

Nielsen, S. B., \& Galamba, K. R. (2010). Facilities Management - When Sustainable Development is Core Business. Paper presented at the European Facility Management Conference 2010, Madrid, Spain.

Nielsen, S. B., Jensen, P. A., \& Jensen, J. O. (2012). The Strategic Facilities Management Organisation in Housing: Implications for Sustainable Facilities Management. International Journal of Facility Management, 3(1).

Ogbeifun, E. (2011). Facilities Management in a Multi-Campus Setting: A Case Study of the University of the Witwatersrand. (Master of Science in Engineering M.Sc.), University of the Witwatersrand, Johannesburg. Retrieved from http://wiredspace.wits.ac.za/bitstream/handle/10539/10585/Edoghogho\%200gbeifun\%20Final.pdf

Pathirage, C., Haigh, R., Amaratunga, D., \& Baldry, D. (2008). Knowledge management practices in facilities organisations: a case study. Journal of Facilities Management, 6(1), 5-22.

Petrini, M., \& Pozzebon, M. (2010). Integrating Sustainability into Business Practices: Learning from Brazilian Firms. Brazilian Administration Review, 7, 362-378.

Porter, T. B. (2008). Managerial applications of corporate social responsibility and systems thinking for achieving sustainability outcomes. Systems Research and Behavioral Science, 25(3), 397-411.

Pullen, S. F. (1999). Consideration of environmental issues when renewing facilities and infrastructure. In M. A. Lacase \& D. J. Vanier (Eds.), Durability of Building Materials and Components 8 (pp. 1778-1786). Ottawa, Canada: Institute for Research in Construction.

Reineck, M., Poltermann, J., May, M., \& Pelzeter, A. (2012). Measuring Corporate Sustainable Development in Facilities Management with Key Performance Indicators. OIDA International Journal of Sustainable Development.

Spangenberg, J. H. (2005). Economic sustainability of the economy: concepts and indicators. International journal of sustainable development, 8(1), 47-64.

Tatum, M. (2013). What is economic sustainability? http://www.wisegeek.org/what-is-economic-sustainability.htm

United Nations Environment Programme. (2009). Buildings and Climate Change: Summary for Decision-Makers: United Nations Environment Programme: Sustainable Buildings \& Climate Initiative.

Warren-Myers, G. (2013). Sustainable management of real estate: is it really sustainability? Journal of sustainable real estate, 4(1), 177-197.

Wood, B. (2006). The role of existing buildings in the sustainability agenda. Facilities, 24(1/2), 61-67. DOI: 10.1108/02632770610639206

Wright, T. S. A., \& Wilton, H. (2012). Facilities management directors' conceptualizations of sustainability in higher education. Journal of Cleaner Production, $31,118-$ 125. DOI: $10.1016 /$ j.jclepro.2012.02.030

Zhang, N., Williams, I. D., Kemp, S., \& Smith, N. F. (2011). Greening academia: Developing sustainable waste management at Higher Education Institutions. Waste Management, 31(7), 1606-1616. 